Bangladesh J. Bot. 48(4): 1115-1124, 2019 (December)

\title{
EFFECTS OF WATER HARVESTING AND ORGANIC FERTILIZER ON VINEYARD (VITIS VINIFERA L.) YIELD AND SOIL MOISTURE CONTENT UNDER ARID CONDITIONS
}

\author{
Meryem KuZucu* \\ Kilis 7 Aralık University Technical Science Vocational School, \\ Department of Plant and Animal Production, Kilis-79000, Turkey
}

Keywords: Water harvesting, Soil moisture, Vineyard, Organic fertilizer, Yield

\begin{abstract}
Water harvesting techniques increase the amount of rainfall per unit area, directing the rainwater to the crop area. The rain water is stored in the soil profile with mulch and similar applications and helps the plant to benefit during the arid periods. Water harvesting techniques can be supported with mulching and fertilizing practices in order to crop yield increase. This study was carried out on 20 years old vineyard in farmers' garden in 2015 - 2016, produced on dry conditions, with economical prescription for Kilis province. Four different doses of leonardite fertilizer were applied in combination with soil bund rainwater harvesting in the experiment. The highest soil moisture was obtained from $370 \mathrm{~mm}$ to $7 \mathrm{~kg}$ /vineyard leonardite application. The maximum plant water consumption was determined to be $389.5 \mathrm{~mm}$ on average from the application of $7 \mathrm{~kg}$ /vineyard fertilizer. The minimum plant water consumption was obtained from the control with 310.7 $\mathrm{mm}$. In terms of yield, there was no difference between 5 and $7 \mathrm{~kg} /$ vineyard leonardite fertilizer.
\end{abstract}

\section{Introduction}

Due to lack of rainfall and drought great difficulties in agricultural production in recent years have been experienced. The lack of rainfall and water resources in a way that cannot be used in agriculture to be irregular and cause erosion leads to damage falling in agriculture. The effects of global warming and climate change lately have led to greater harm in the arid regions as well as being effective in Turkey. Southeast Anatolia region is one of the areas most affected by this situation. Besides the average annual precipitation is very low, rainfall irregularity and severity damage the agricultural areas in this region as soil erosion. Low and inefficient rainwater (which does not benefit any living organisms) falling in arid and semi-arid areas needs to be accumulated in situ or stored on surface stream.

Plant nutrients usefulness is possible only by the presence of water. Dry agricultural areas are experiencing low yield due to these insufficiencies. Water harvesting methods are applied since these started living with humans and crop production in arid areas. This technique, which was used in West Asia and North Africa in the 4500's BC, helps the people to get along with agricultural production. At present arid countries such as Yemen, Libya, Tunisia, Algeria, Morocco and Syria, are using rainwater harvesting techniques for drinking and irrigation purposes. The common aim of agricultural water harvesting efforts is to collect and evaluate rainwater in the root region of the plant, to increase and accumulate soil moisture by supporting rainfall, plants growth and development with increase crop yield and agriculture productivity. It prevents soil erosion with some mulch applications (Kuzucu 2013). Some of water harvesting techniques as semi-circular soil bunds or trapezoidal bunds established for some tree species are economical techniques and easy that do not require the implementation labor force. They are called semicircular soil bunds and are made in the slope direction for conserving water and surface soil. These soil bunds are used annual rainfall of more than $300 \mathrm{~mm}$ and a slope of $0.5-5 \%$ arid areas. The

*Author for correspondence: <mrymgunes@gmail.com>. 
soil bunds are constructed at $1-8 \mathrm{~m}$ wide and $0.5 \mathrm{~m}$ high in the direction of slope (Oweis et al. 2001)., In the semi-arid regions to determine soil moisture and water use efficiency Xiao-Yan et al. (2003) used dry maize production plastic mulching, gravel ridge and furrow combinations. When bare ridges average rainfall efficiency is determined $7 \%$, plastic mulch ridges average rainfall efficiency is $87 \%$. Abu-Zreig et al. (2000), carried out water harvesting studies with soil bunds applied for feeding olive trees in rainwater in Jordan. The amount of rainwater stored soil bunds compared to the control subjects showed $78 \%$ in soil bunds and $45 \%$ in control trenches in the soil profile. Fooladmand et al. (2004), used micro-cathcment water harvesting systems in Iran, worked on economic analysis for cultivated grape cultivation. The grape orchard was $5-6 \%$ inclined sandy loam soil and water harvesting system has been established $3 \mathrm{~m} \times 3 \mathrm{~m}$ in dimensions of $9 \mathrm{~m}^{2}$ area. Each of grape yields was $40 \%$ more than the conventional grape production. Xiao-Yan et al. (2006), suggested to their study of the growth of the Tamarix tree that the effects of rainwater storage on soil moisture and plant growth; tree height, crown diameter and trunk circumference increased by 70,57 and 79\%, respectively. Wang et al. (2008) investigated the effects of application of rainwater harvesting ridge and furrows on runoff efficiency and potato yield in semi-arid regions of China. Plastic mulching ridges increased tuber yield by $158-176 \%$ compared to the control, while compressed ridges increased tuber yield by $14,9-28,4 \%$ compared to the control. Soil water content is higher plastic mulching ridges than compressed ridges, while soil moisture accumulation of two treatments is considerably greater than control. Tubeileh et al. (2008) have examined the effects of water harvesting on the young olive trees in the degraded arid lands of Syria. Different micro basin sizes have been tested in sloping areas. The results showed that water harvesting and summer irrigation improved soil moisture content. In September, leaf water content increased by $36 \%$, leaf nitrogen content increased by $45 \%$ in August, leaf stoma conduction and relative body growth also increased. Despite the inadequate soil water storage capacity, it conserved soil water. The water harvest was found to be more successful during the rainy years in the study. The drought-tolerant olive used in this study also showed that it could be grown with little or no irrigation water. Abu-Zreig et al. (2011) conducted a field trial for moisture and soil conservation using a water harvesting technique called sand ditch to evaluate a new water harvesting technique in Jordan. The sand-ditch technique reduces substantial amount surface runoff and sediment losses compared to the control, this application has increased infiltration and soil moisture conservation. Runoff flow and sediment losses have decreased by 46 and $61 \%$, respectively compared to the control in the sand ditch technique parcels. Semi-circular soil bunds are one of the most economical and successful techniques used to conserve rainwater in arid areas. Water harvesting techniques can increase runoff efficiency with mulch applications, while with fertilizer applications can provide increased crop yields. Prefer natural fertilizers to increase soil fertility is the best way to ensure the sustainability of the soil. (Kuzucu 2017). Semi-circular soil bunds were obtained from traditional farmer application with the lowest average yield of $14,30 \mathrm{~kg} /$ tree while the highest yield was obtained with pistachio at $24.65 \mathrm{~kg} /$ tree with application of water harvesting soil bunds and farm fertilizer. Herbal and animal origin, organic materials, origin are the source of energy for the microorganisms present in the soil. Humic and fulvic acids, which are the result of decomposition of organic materials, have represented soil fertility. Leonardite, which is a humic acid derived from organic fertilizers, increases the soil organic matter; improves the soil physical structure, increases the soil water holding capacity, helps to easily soil heating and prevent the erosion by reducing the soil slip layer and soil surface cracking.

Water harvesting techniques were used semi-circular soil bunds to provide collecting soil moisture and increasing yield. The aim of this study is, to collect the rainwater and accumulate it in the soil in dry grape orchard at the same time reduce the drought damages and increase grape 
yield. Semi-circular soil bunds which have been designed $30 \mathrm{~cm}$ high and $30 \mathrm{~cm}$ wide, eyebrowshaped, have covered the vineyards crown projection. As a result of the findings obtained in this study, water harvesting techniques in dry farming areas based on rainwater, as in the province of Kilis, not only soil moisture conservation but also provide increase plant water consumption and increase crop productivity. Obtainable from naturally rain water and would be an economic gain that water harvesting techniques will be useful to the farmers while combined use with organic fertilizer soil moisture maintaining and can be provide increase grape yield on non-irrigation vineyard orchards.

\section{Materials and Methods}

This work was conducted between 2015 and 2016, consisting of Horozkaras1 grape varieties and 20-years old yields age in farmer gardens in Kilis. Kilis province has reddish brown soil. This soil's lime content is high and organic matter amount is low clay textured soil. Due to the low organic matter content lack of rainfall with lack of vegetation cover to the soil, the accelerated small amount of organic material decomposition formed by successive rainy and dry periods. Kilis province is under Mediterranean climate effects. General characteristics of climate; summers are very hot and arid, winters are warm and rainy. Long time average precipitation of study area is presented in Fig. 1. Study area soil properties are presented in Table 1. Trial field long time average temperature is given in Fig. 2.

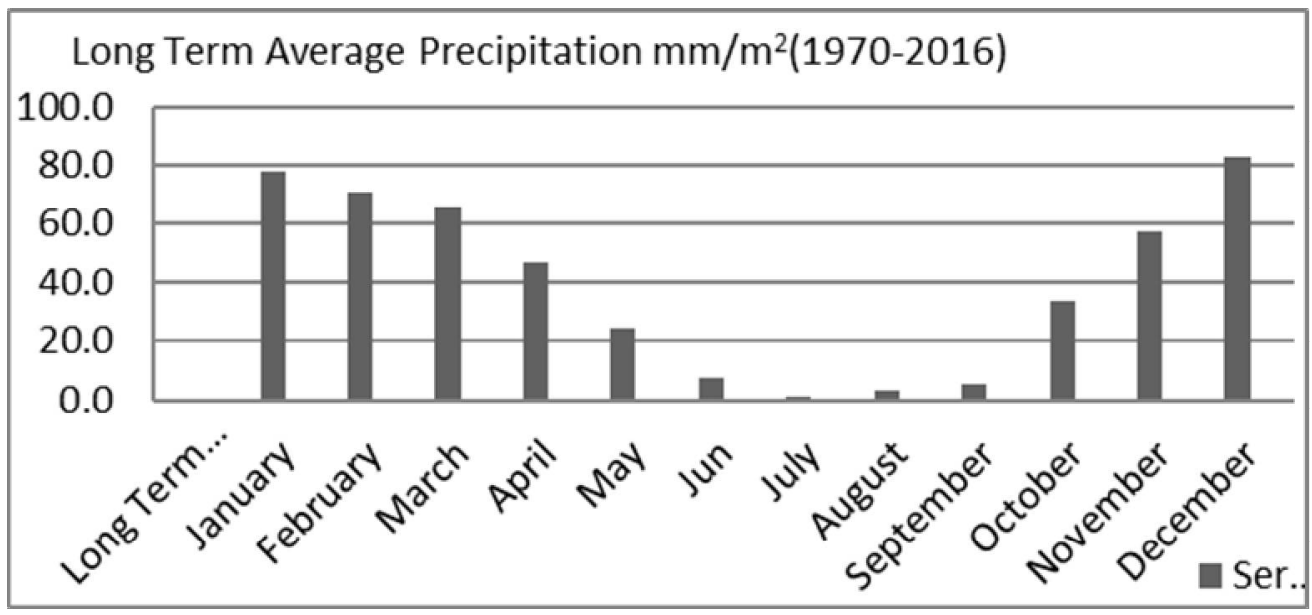

Fig. 1. Study area long term average rainfall.

Table 1. Some soil physico-chemical properties of treatment areas.

\begin{tabular}{llllllll}
\hline $\begin{array}{l}\text { Soil depth } \\
(\mathrm{cm})\end{array}$ & Texture & $\mathrm{pH}$ & $\begin{array}{l}\text { Bulk density } \\
\left(\mathrm{g} / \mathrm{cm}^{3}\right)\end{array}$ & $\begin{array}{l}\mathrm{CaCO}_{3} \\
(\%)\end{array}$ & $\begin{array}{l}\mathrm{P}_{2} \mathrm{O}_{5} \\
(\mathrm{~kg} / \mathrm{da})\end{array}$ & $\begin{array}{l}\mathrm{K}_{2} \mathrm{O} \\
(\mathrm{kg} / \mathrm{da})\end{array}$ & $\begin{array}{l}\text { Organic } \\
\text { matter }(\%)\end{array}$ \\
\hline $0-30$ & Clay-loam & 7.76 & 1.24 & 35.00 & 1.52 & 119.1 & 1.01 \\
$30-60$ & Clay & 7.73 & 1.26 & 36.40 & 1.37 & 54.7 & 0.92 \\
$60-90$ & Clay-loam & 7.75 & 1.26 & 37.20 & 1.10 & 52.8 & 0.84 \\
\hline
\end{tabular}




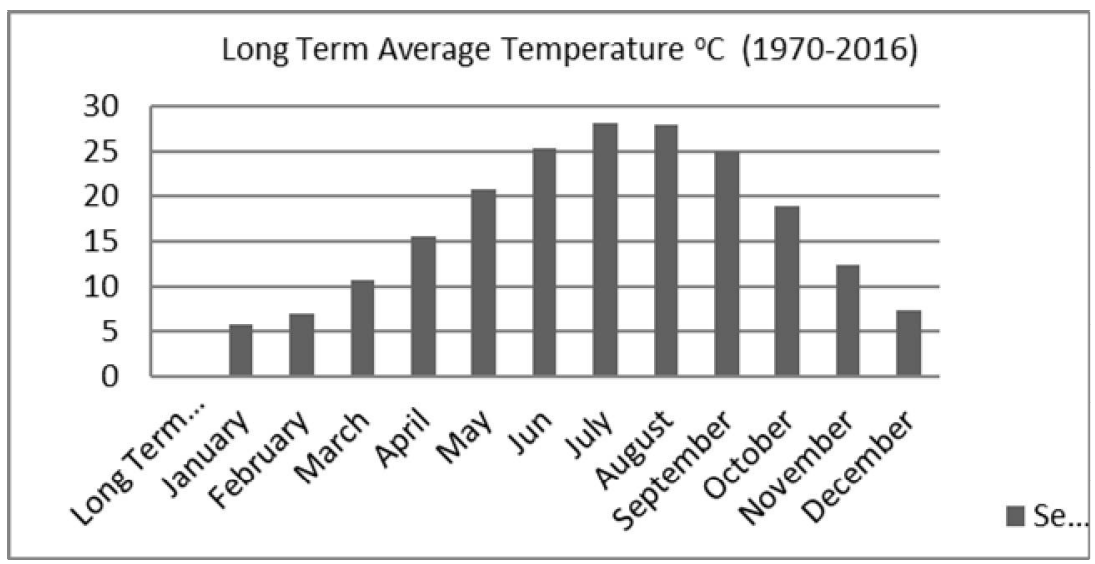

Fig. 2. Study area long term average temperature.

Semi-circular soil bunds water harvesting technique can use some fruit trees and shrubs, does not require labor force easy establish and quite economic technique. These soil bunds are designed the direction of slope semicircular shape, a crescent shape or trapezoidal shapes. Generally, as a result of applications between two plants as a surface compacting or mulching, rainwater flow as runoff and accumulated in the plant root zone (Fig. 3).

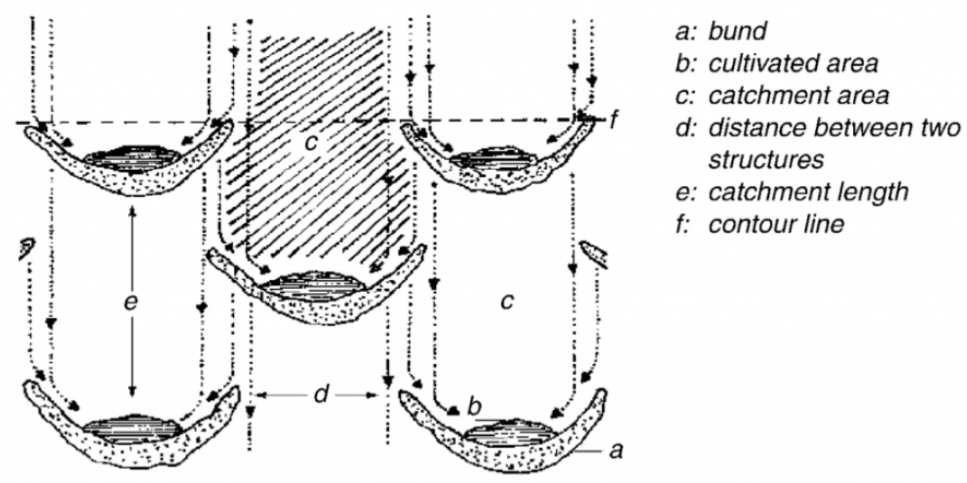

Fig. 3. Semi-circular soil bunds (Oweis et al. 2001).

Semicircular soil bunds water harvesting technique was used to provide soil moisture conservation and increase crop yield. It was built in the shape of a brow, $30 \mathrm{~cm}$ high and $30 \mathrm{~cm}$ wide, covering the crown projection in the vineyards before the rains in September. Between two vineyards collected total precipitation was directed towards the plant root zone by surface compaction. The study was established three different doses of leonardite fertilizer as 3 replications according to randomized parcel trial design. Each experiment topic has 3 grape vineyards and total of 36 grape vineyards were in this study (Fig. 4).

S0: Conventional farmer application (control). The method applied by the farmers who produce roasted grapes in the traditional farmer application has continued in the same way and no fertilization has been applied. Only soil tillage was carried out.

S1: Three kg/vineyard leonardite fertilizer + soil bund water harvesting. 
S2: $5 \mathrm{~kg} / \mathrm{vineyard}$ leonardite fertilizer + soil bund water harvesting.

S3: $7 \mathrm{~kg} / \mathrm{vineyard}$ leonardite fertilizer + soil bund water harvesting.

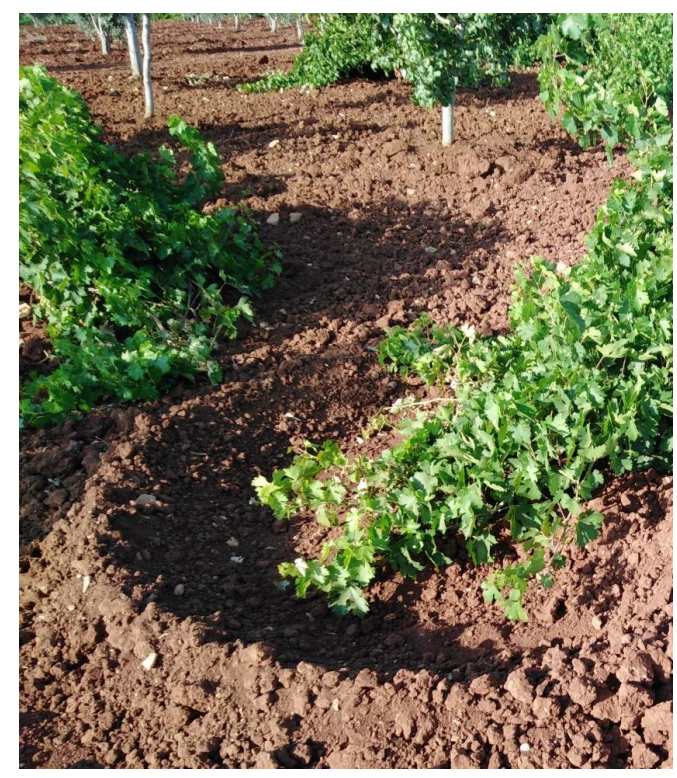

Fig. 4. Semi-circular soil bunds in research area in Kilis

Leonardite fertilizer used in the experiment contains $60 \%$ organic matter. Leonardite, apart from humic acids at high levels contains carbon, macro and micro nutrients. Leonardite is known to have an average moisture content of $30 \%$.

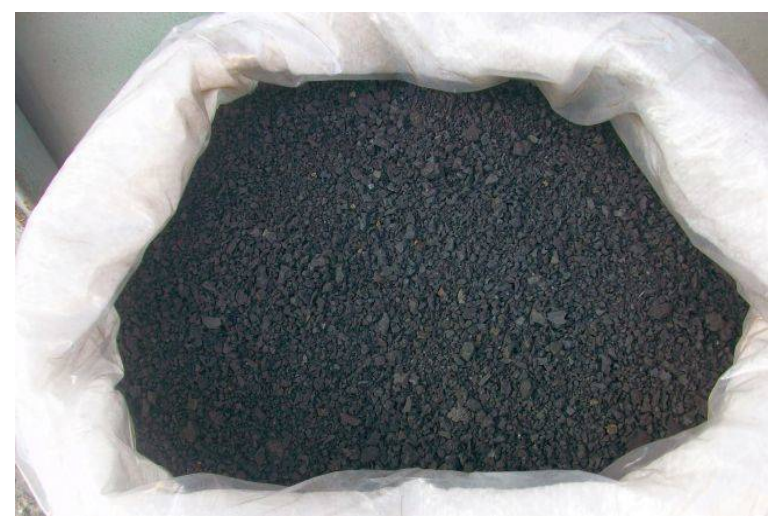

Fig. 5. Leonardit fertilizer.

Before designed soil bunds, leonardite fertilizer has been applied around vineyard $25 \mathrm{~cm}$ in soil depth and covered with soil (Fig. 5).

Soil water content was measured by gravimetric method in soil samples from soil $0-30 \mathrm{~cm}$, $30-60 \mathrm{~cm}$ and $60-90 \mathrm{~cm}$ depths. 
Plant evapotranspiration (ET-mm) was determined by the following formula:

$$
\mathrm{ET}=\Delta \mathrm{W}+\mathrm{P}+\mathrm{I} \pm \mathrm{D}
$$

where, $\Delta \mathrm{W}$ is the change in soil water storage $(\mathrm{mm}), \mathrm{P}$ is the precipitation $(\mathrm{mm}), \mathrm{I}$ is the amount of irrigation ( $\mathrm{mm}$ ), which was measured using a water meter, and D is the amount of water lost due to deep drainage (mm) which was negligible in this study (James 1988). Plant water consumption value was calculated by using the soil water balance equation.

Fruit yield was calculated from each vineyard grape fruit. Average yield was determined as per plant $\mathrm{kg} /$ vineyard in this orchard.

The results were subjected to analysis of variance and LSD test was applied to differences classification Açıkgöz et al. (1994). During the harvest period grape yield weight was calculated per vineyard.

\section{Results and Discussion}

Kilis province receives almost no precipitation during June and September. Plants need water in this arid period. During the arid summer, plants get dry or fruit cracking and quality losses and low yield. Rainwater harvesting techniques are the best solution in order to minimize the loss of these conditions which are expensive for grape producers.

In the first year of the study total precipitation was $560.3 \mathrm{~kg} / \mathrm{m}^{2}$, in the second year it was $354,4 \mathrm{~kg} / \mathrm{m}^{2}$. In February of 2015 water year total precipitation was $146.2 \mathrm{~kg} / \mathrm{m}^{2}$, while in the same period in 2016 February total precipitation was $15.6 \mathrm{~kg} / \mathrm{m}^{2}$. This is due to climate change effects; rainfall decreased year by year and became irregular in this region (Fig. 6). The soil moisture kept in the plant root zone was measured $364.5 \mathrm{~mm} / 90 \mathrm{~cm}$ in $0-90 \mathrm{~cm}$ soil depth after each precipitation and their averages were calculated. According to the results, the maximum amount of soil moisture was obtained after $7 \mathrm{~kg}$ leonardite application. The lowest soil moisture was obtained from conventional production application with $256.20 \mathrm{~mm} / 90 \mathrm{~cm}$ (Table 2). Soil moisture was found to increase in the study's second year; there was no statistically significant difference between $5 \mathrm{~kg} /$ vineyard and $7 \mathrm{~kg} /$ vineyard after leonardit applications. With organic fertilization, the soil physical conditions have improved and the soil moisture content has increased. Soil moisture has increased as organic fertilizer doses have increased. Water harvesting practices increased soil moisture according to the control application. Water harvesting has been found useful for arid soils (Serpantie et al. 1992, Oweis and Taimeh 1994, Zhang and An 1997), in which micro-catchments techniques are used with mulching, ridge and furrow application and can provide rainwater is stored in the soil depth Yuan et al. (2003), Wang et al. (2008).

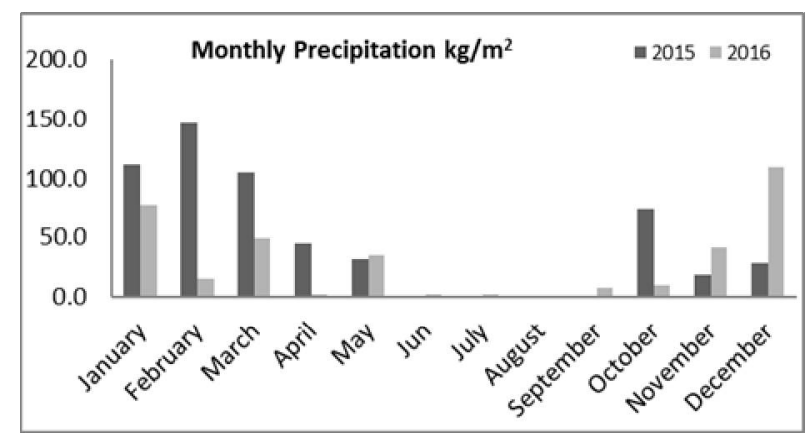

Fig. 6. Precipitation data (2015 - 2016 water years). 
Table 2. Average soil moisture content $(0-90 \mathrm{~cm})$.

\begin{tabular}{lll}
\hline Treatments & $\begin{array}{l}\text { Average soil moisture } 2015 \\
\text { water year }(\mathrm{mm})(0-90 \mathrm{~cm})\end{array}$ & $\begin{array}{l}\text { Average soil moisture } 2016 \\
\text { water year }(\mathrm{mm})(0-90 \mathrm{~cm})\end{array}$ \\
\hline $\begin{array}{l}\text { S0: Conventional (Control) } \\
\text { S1: 3 kg/vineyard leonardite fertilizer }+\end{array}$ & $\begin{array}{l}256,20 \mathrm{c} \\
\text { 30il bund water harvesting }\end{array}$ & $338,50 \mathrm{c}$ \\
$\begin{array}{l}\text { S2: } 5 \mathrm{~kg} / \text { vineyard leonardite fertilizer }+ \\
\text { soil bund water harvesting }\end{array}$ & $389,12 \mathrm{~b}$ \\
$\begin{array}{l}\text { S3: } 7 \mathrm{~kg} / \text { vineyard leonardite fertilizer }+ \\
\text { soil bund water harvesting }\end{array}$ & $397,60 \mathrm{a}$ & $376,90 \mathrm{a}$ \\
LSD $(\%$ 5) & $1,26^{*}$ & $384,50 \mathrm{a}$ \\
\hline
\end{tabular}

*Significant treatment effect in ANOVA at $\mathrm{p} \leq 0.05$, Value is the average of 3 replicates. Averages are shown with the same letter in the same group there was no difference between the levels of $p<0.05$.

Water harvesting semi-circular soil bunds technique was transmitted rainfall that fall between two grape plants to the plant root zone, thus rainfall amount was found to increase per unit area. Despite the less precipitation was fall in the 2016 water year; tanks to semi-circular soil bunds technique and organic fertilization useful effects were high soil moisture amount in the soil in second research year (Table 2).

ET has increased linearly with the amount of rainfall. Plant water consumption was high in the experiment's first year, while in the second year it was found to be low due to low rainfall. Doorenbos and Kassam (1979), Grimes and Williams (1990) reported that the amount of seasonal plant water consumption is between 500 and $1200 \mathrm{~mm}$. (Kuzucu 2013). Mulch applications with micro-catchment water harvesting technique; the best plant water consumption and best plant growth was obtained from plastic mulching water harvesting application in non-irrigation pistachio trees in Southeast of Turkey.

Plants get water from rainwater as well as from collected amount of rainwater. There was no statistical difference between 5 and $7 \mathrm{~kg}$ doses of organic fertilizer on plant water consumption. The highest water consumption was obtained from the S3 with $382.4 \mathrm{~mm}$ in 2015 water year. The lowest consumption was measured from S0 with $202.5 \mathrm{~mm}$ since there was no rain water collecting application (Fig. 7). Semi-circular soil bunds are the most economical and easily applicable techniques to collected rainwater in arid agriculture lands. If they are disrupted in extreme rainfall, it must be repaired (Kuzucu 2017).

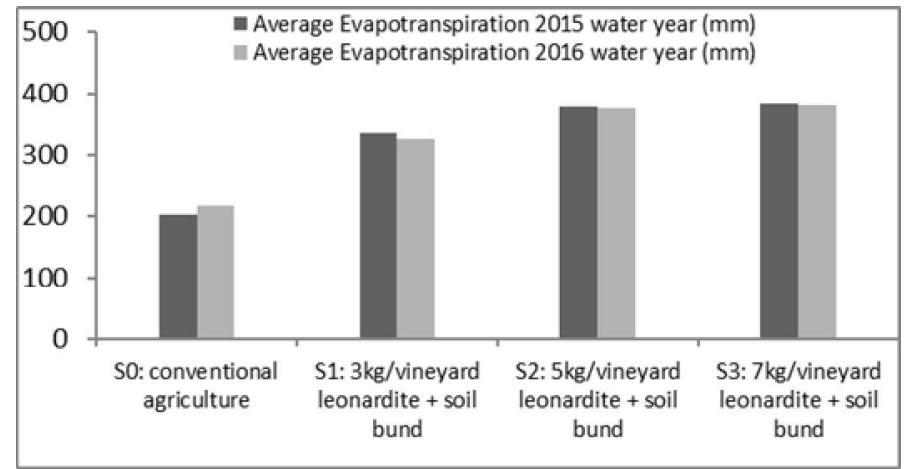

Fig. 7. Plant evapotranspiration 2015 - 2016 water years. 
There was no statistically significant difference between 5 and $7 \mathrm{~kg}$ of organic fertilizer doses per vineyard in terms of grape yield. The highest average yield was obtained from $7 \mathrm{~kg} / \mathrm{vineyard}$ leonardite application with $23.8 \mathrm{~kg} /$ vineyard and the lowest yield was obtained from traditional application with $10.2 \mathrm{~kg} /$ vineyard. Semi-circular soil bunds and organic fertilization caused yield increase per vineyard in arid condition. As the plant root zone water amount was increased, organic matter was dissolved and grape yield increased. According to the control application, applied organic fertilizer doses have increased as well as grape yield has increased. Semicircular soil bund water harvesting and organic fertilization applications increased yield by $81 \%$ compared to the control. More than half of Turkey's soil is poor in organic matter. Farmers engaged in agricultural production should use organic fertilizer and it should be supported in this regard. Water harvesting practices is useful for arid lands. It can provide crop yield with minimum rainfall. The most important goal is to increase soil fertility and yield with organic fertilizers using in semi-arid agriculture areas. Organic fertilizers uses has been increased fruit yield in conventional agricultural products (Kuzucu 2017).

There was a significant $(\mathrm{p}<0.05)$ linear relationship between seasonal water consumption and yield. It has been revealed that there is a linear relationship between plant water consumption and yield. As the rainfall increases, the soil moisture increases and the plant water consumption increases as moisture accumulates in the soil. As the plant water consumption increased, grape yield increased linearly (Fig. 9).

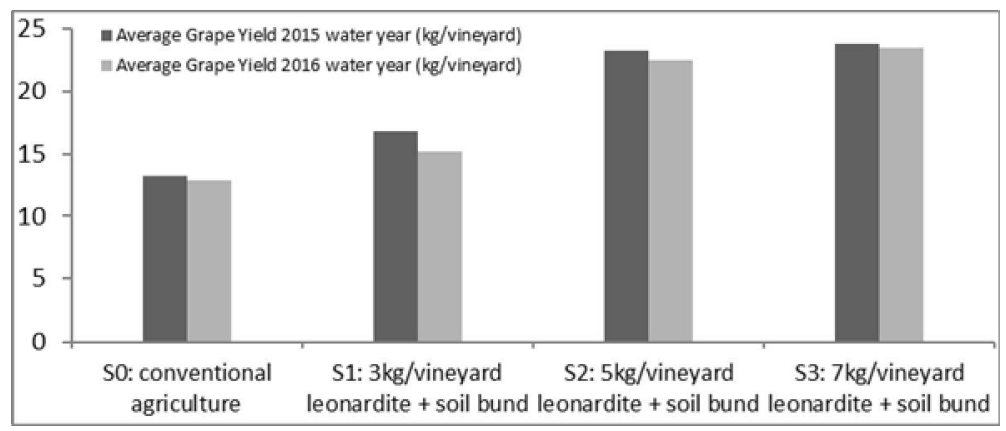

Fig. 8. Average yield 2015 - 2016 water years.

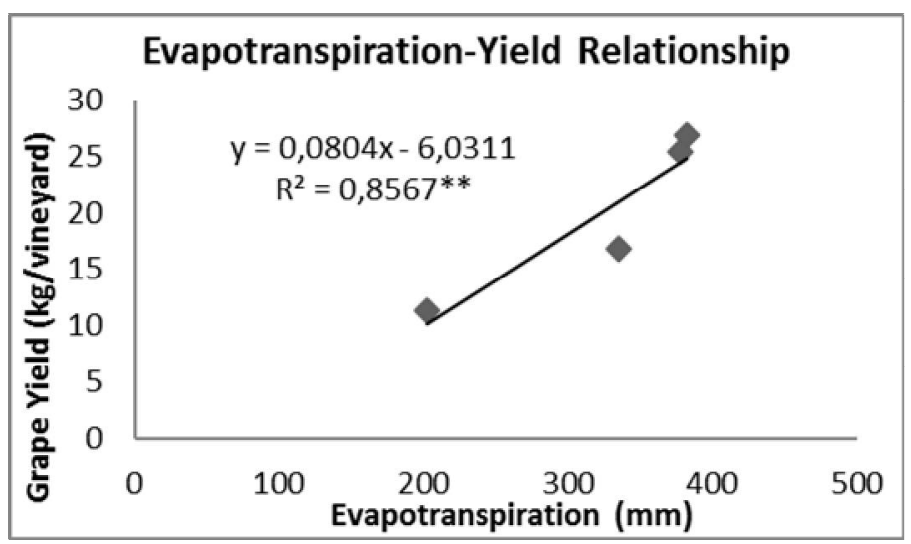

Fig. 9. Plant evapotranspiration yield relationship 2015-2016 water years. 
Ferreyra et al. (2004) have reported that water content reduces grapes grain size and shoot growth and, consequently caused low yield.

They determined that irrigation water a quantity has increased depends on grape yield values increased and the yield difference was $20 \%$ between the irrigation and non-irrigation subject.

We need to benefit from natural resources as a precipitation in agricultural production. It is aimed to get the highest efficiency with the natural resources in agricultural production in poor country in the world. The most important goal is to increase soil fertility and yield with organic fertilizers using in arid agriculture areas. Organic fertilizers uses has been increased crop yield in conventional agricultural products. Rainwater should be best assessed in rainwater fed dry farming areas. Storing rainwater in a place or it is necessary to increase the amount of rainfall per unit area by directing the crop to the field. Semi-circular soil technique was used in this study which is an economical technique from water harvesting techniques, and positive results were obtained. The water harvesting technique was supported by leonardite, an organic fertilizer, to increase soil moisture more than the control in the field. Water harvesting and leonardite application increased soil moisture by 55\% compared to the conventional grape production. Similar results were obtained with 5 and $7 \mathrm{~kg}$ leonardite application in terms of soil moisture conservation. The more soil moisture has accumulated in the soil, the more plants have benefited from soil water tanks to water harvesting and organic fertilizer. Water harvesting and organic fertilizer application plants were more fed rainwater than control plants. The highest consumption was $382.4 \mathrm{~mm}$ with 7 $\mathrm{kg} / \mathrm{vineyard}$ leonardite, while the lowest consumption was $202.5 \mathrm{~mm}$ with control. In terms of grape yield, the differences of the best and the least grape yield was $7.6 \mathrm{~kg}$. As a result of this study, semi-circular soil bund water harvesting technique, is recommended to the farmers who used non-fertilizer and non-irrigation grape production under dry conditions. This technique is economical and easy to evaluate by directing rain water to plant root zone in order to using arid periods. Water harvesting techniques use rainwater, so it is free and economical. It should be supplemented with organic fertilizers to ensure agricultural production sustainability by protecting the soil and environment in arid climates. Since 5 and $7 \mathrm{~kg}$ doses of the organic fertilizer leonardite gave similar results, it may be recommended that $5 \mathrm{~kg} /$ vineyard leonardite would be economic to the grape producer farmers in the arid region.

\section{References}

Abu-Zreig, M Attom M and Hamasha N 2000. Rainfall harvesting using sand ditches in Jordan. Agricultural Water Management. 46(2): 183-192.

Abu-Zreig M and Tamimi A 2011. Field evolution of sand-ditch water harvesting technique in Jordan. Agricultural Water Management, 98: 1291-1296.

Açıkgöz N Aktaş M E Mokhaddam A F and Özcan K 1994. Tarist an agroistatistical package programme for personel computer. E.Ü.Z.F. Tarla Bitkileri Kongresi, İzmir.

Doorenbos J and Kassam AH 1979. Yield response to water. FAO. Irrigation and Darainage Paper. Rome. No: 33.

Grimes DW and Williams LE 1990. Irrigation effects on plant water relations and productivity of thompson seedless grapevines. Crop Science Soc. Am. 30: 255-260.

Ferreyra RE Selles GV and Parelta JA and Valenzuela JB 2004. Effect of water stress applied at different development periods of cabernet sauvignon grapevine on production and wine quality. International Symposium on Irrigation and Water Relations in Grapevine and Fruit Trees ISHS Acta Horticulture. 646.

James L G 1988. Principles of Farm Irrigation System Design. Jhon Wiley ans Sons. Inc. USA. p. 543. 
Kuzucu M 2013. Effects of micro-cathcment water harvesting technique on young pistachio trees growth, soil and water conservation in semi- arid areas. Unpublished Ph.D. Thesis. Çukurova University Department of Soil Science and Plant Nutrition. Adana, Turkey.

Kuzucu M 2017. Effects of water harvesting techniques and using humic acid on soil moisture, plant evaporation, growth and yield in pistachio orchards in southeastern of Turkey. Fresenius Environmental Bulletin 26(12): 7521-7528.

Oweis T and Taimeh A 1994. Overall evaluation of on-farm water harvesting systems in the arid regions. International Conference on Land and Water Resources Management in the Mediterranean Region, Valenzano, Bari, Italy 4-8 September, 1994. No.3, 763-781; 13 ref.

Oweis T Prinz D and Hachum A 2001. Water harvesting 1ndigenous knowledge for the future of the drier environments, International Center for Agricultural Research in the Areas (ICARDA), Aleppo, Syria.

Serpantie G Lamachere JM Hurn1, H and Tato K 1992. Contour stone bunds for water harvesting on cultivated land in the north yatenga region of Burkina Faso. Erosion, Conservation, And Small Scale Farming, 459-469; 3 Ref.

Tubeileh A, Bruggeman A and Turkelboom F 2009. Effects of water harvesting on growth of young olive trees in degraded Syrian dryland. Environment, Development and Sustainability 11(5): 1073-1090.

Wang Y Xie S and Cecil LM 2008. Effects of rainfall harvesting and mulching technologies on water use efficiency and crop yield in the semi-arid loess plateau, China. Agricultural Water Management 96(3): 374-382.

Xiao-Yan L Zhong-Kui X and Xiang-Kui Y 2003. Runoff characteristics of artificial catchment materials for rainwater harvesting in the semiarid regions of China. Journal of Agricultural Water Management. 65(3): 211-224.

Xiao-Yan L Zhao W Song X Wang W and Zhang Y 2006. Rainfall harvesting on slopes using contour furrows with plastic-covered transverse ridges for growing caragana korshinskii in the semi-arid region of China. Agricultural Water Management. 95(5): 539-544.

Yuan T Fengmın L and Puha1 L 2003. Economic analysis of rainwater harvesting and arrigation methods, with an example from China. Agricultural Water Management 60: 217-226.

Zhang XB and An ZS 1997. Reducing the ground evaporation and using the precipitation resource fully. Bull. Soil Water Conservation, 17(1): 57-62.

(Manuscript received on 8 October, 2018; revised on 21 January, 2019) 